\title{
Survey on Reviews of Global Piracy Activities and the Response Measures
}

\author{
Qian Wang ${ }^{1}$, Peng Tao ${ }^{2}$ \\ ${ }^{1}$ Navigation College, Shandong Jiaotong University, Weihai, China \\ ${ }^{2}$ Shandong New Beiyang Information Technology Co., Ltd., Weihai, China
}

Keywords: piracy activities; international organizations; response measures

Abstract: All those interviewed agree that pirate activity has greatly diminished since its peak. These results are inseparable from the fighting piracy activities of many countries and international organizations. This paper studies on the reviews of the fighting piracy actions and reports of related organizations, and gives the suggestions on the response measures of shipping company and seaman.

\section{Introduction}

Global piracy activities intensified since 1980's. Piracy has a significant impact on the navigation safety.

\subsection{The impact on the safety of life at sea}

Piracy is often accompanied by violence and it is a great threat for the life safety of crew. In the pirate attacks, injuries, death and disappearances of crew members caused by hijacking and beating happened occasionally.

\subsection{The impact on the property safety}

Piracy has brought serious economic loss to the world. The impact of piracy on water property safety is mainly performance in the following aspects: ship sinking damage, loss of cargo, paying ransoms, the increasing premium, shipment delay and increased investment in security of ship companies. And the indirect loss is much greater than the direct loss.

\subsection{The impact on the environment safety}

Pirate attacks to oil ships, offshore oil platforms and chemical tanker ships, will cause the crude oil and chemical spills, and then bring serious environment disaster to the water.

\subsection{The impact on the ship navigation safety}

Pirates may also bring adverse impact on the navigation safety of important channels. For example, the Strait of Malacca, its narrowest place is only $37 \mathrm{~km}$, and the shallowest is less than $25 \mathrm{~m}$.If the ship sunk or ran aground by attacks in the shallow water, that would seriously influence the ship navigation safety, even blocked the channel.

\section{The international legal basis for the repression of piracy}

\subsection{UNCLOS1982 (United Nations Convention On the Law of the Sea, 1982)}

As prescribed in article 100 of the Convention, all States shall co-operate to the fullest possible extent in the repression of piracy on the high seas or in any other place outside the jurisdiction of any State.

\subsection{The Rome Convention1988 (Convention for the Suppression of Unlawful Acts Against the Safety of Maritime Navigation, 1988)}

Because of the UNCLOS1982 only limited piracy on the high seas, IMO (International Maritime Organization) set out a new convention that is The Rome Convention1988. The Rome Convention emphasizes that the act location of piracy includes territorial sea of each State Party. Each State 
Party shall take such measures as may be necessary to establish its jurisdiction over the piracy act set forth.

\section{International effort to crack down on piracy}

According to the international maritime organization's annual report, two or three hundred global pirate attack cases happened each year since1998, in 2009, the pirate cases increased up to nearly five hundred. In 2016, pirate attacks reduced to the lowest level of recent twenty years, according to the analysis report of the International Maritime Bureau. The decrease of pirate attacks on ship cases is inseparable with the global jointly combating piracy measures.

\subsection{Union Nation's authorization of national army}

Since 2006, the rampant acts of Somalia pirates have caused a serious hazard to international shipping and the safety of maritime navigation. On the basis of the International Law, The United Nations Security council passed a resolution in 2008, which authorized foreign troops in Somalia's territorial waters to combat piracy and armed robbery at sea. The UN extended this authorization to this day. The Security Council had adopted a resolution Nos. 2446(2015), which determined every country and regional organizations to cooperate with Somalia authorities to combat piracy and armed robbery at sea for one more year. And we realize pirates are endangering the Somalia situation through other criminal activities. In order to combat the other types of crime which cause the instability in Somalia, the Security Council extended the authorization for foreign army to November 2016.

On the basis of international law and UN authority, many countries send military forces to escort merchant ship and combat piracy in the Gulf of Aden waters. Chinese navy sent the first convoy to escort missions in the Gulf of Aden off the waters of Somalia in December 2008.

\subsection{The Djibouti Code of Conduct}

Aiming at the sea the Gulf of Aden armed robbery crime, IMO (International maritime organization) held a 17countries headings 'meeting in Djibouti, in which agreed a code. It is about fighting the western Indian Ocean and the Gulf of Aden of piracy and armed robbery at sea behavior rules, named "the Djibouti Code of Conduct". The Code of Conduct requires signatories to comprehensively cooperate under the framework of International Law, share and change related information, crack down the crime ships at sea, arrest and prosecute criminals at sea, protect and escort the suffers.

The Djibouti Code of Conduct comes into effect on January 29, 2009.

\section{Analysis reports of global anti-piracy organizations}

\subsection{OBP (Ocean Beyond Piracy)}

OBP publishes the researches on anti-piracy report every year.

In 2014, America anti-piracy research organization “Ocean Beyond Piracy "published Pirates situation in 2013.The report said the Somalia pirates force decreased obviously, and the total economic cost reduced by $50 \%$ to 32 billion dollars. However, the piracy in the Gulf of Guinea is increasingly rampant.

On May 3, 2016, London OBP published the report on the anti-piracy countries situation, which summarized and reviewed the related work of IMO. Activities to combat piracy of IMO includes: creating the GISIS database about the ship report on the piracy and robbery, setting up a series of preventing, combating piracy and later investigation guild lines which includes the ship armed security guidelines and successful regional activities.

In 2016, America OBP report that the attacks in the Gulf of Guinea, which is the main source of oil cocoa and metal, tapers off, partly because of the patrol in the area and lowered oil prices. 


\subsection{ReCAAP (The Regional Cooperation Agreement on Combating Piracy and Armed Robbery against ships in Asia)}

The ReCAAP is the first regional government-to-government agreement to promote and enhance cooperation against piracy and armed robbery in Asia. To date, 20 States have become Contracting Parties to ReCAAP, which include 14 Asia countries and 6 countries outside of Asia. The ReCAAP Information Sharing Center (ISC) was established under the ReCAAP Agreement. The roles of ReCAAP ISC include exchanging information among Contracting Parties on incidents of piracy and armed robbery supports capacity building efforts of Contracting Parties, and for cooperative arrangements.

The ReCAAP ISC said, as the Figure1described, that 59 incidents had been reported during the period from January to September 2016 in Asia, highlighting a sharp decrease of 65\% compared to last year. ReCAAP ISC noted that the improvement of the piracy status in the Straits of Malacca and Singapore had contributed to the overall reported number as only 2 incidents had reported this year, compared to 96 in 2015.

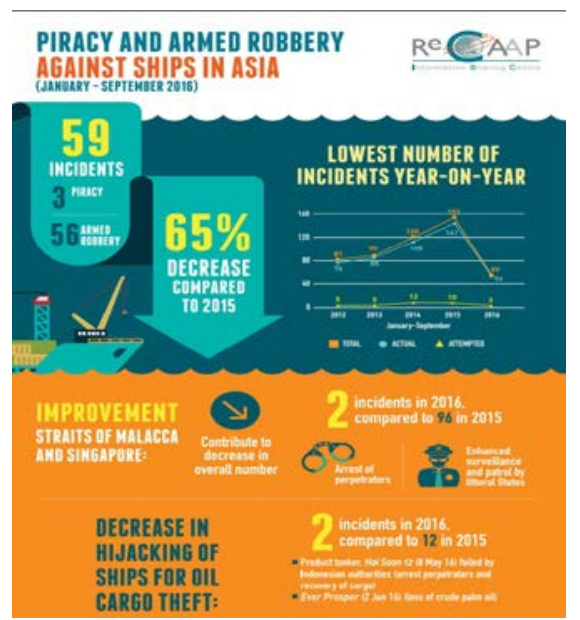

Figure 1: Piracy and armed robbery in Asia

Source: ReCAAP ISC report (1-9)2016.

ReCAAP ISC recommends the following best practices:

Vigilance of crew;

Immediate operational responses - arrest;

Effective and efficient information sharing and operational response among littoral States;

Collaboration between shipping industries with authorities.

\section{Future prospects of piracy problems}

98 incidents have been reported globally in the first half of this year, a decrease compared to last year. And the number of incidents is the least since 1995. It is an inspirational thing, which is connected with the improvement of the piracy status in Indonesia and Somalia of East Africa. But the attacks in the Gulf of Guinea and Nigeria also need place more attention.

As a tracking sea violence research institution, American OBP says, in the future year, main work should focus on three key areas:

\subsection{Solving the problem of piracy also need a long time, but transparent and inter sectional actions have been accepted widely and been proved successful}

So inter sectional cooperation is considered a long global solution. OBP promotes and encourages the cooperation of all departments to combat piracy.

\subsection{Sailors and fishermen are the most vulnerable to violence at sea}

OBP wishes improve their safety by strengthening the accident report and ensure to strengthen 
the basic training in the high-risk area. For hostages held in Somalia, OBP will give help.

\subsection{The problem of piracy and armed robbery remains unsettled}

The international community must remain on high alert, and pay attention to the high-risk area.

\subsection{The response measures of shipping company and seaman}

The shipping industry cannot rely on the navies and traditional law enforcement to protect them from pirate attacks and to hold pirates accountable. Patrolling the open waters is different from patrolling on land, crime is easier to perpetrate, harder to detect and harder to prevent. So the shipping company and the seaman should take response measures to deal with. In fact, Piracy is not success every time. In the recorded pirate attacks, about a third of the record are attempted attacks. As long as prepared, pirates are not necessarily successful. Through a lot of analysis and study concluded that self prevention and counter attack on merchant ships to repel the pirates is a $78 \%$ chance of success. Thus the structure and equipment modification of the shipping company to deal with the pirates, and the seamen self prevention act can effectively scare off pirate attacks 。

\subsection{The strategy of shipping company}

In view of the piracy is rampant, the shipping company installs easy anti-piracy devices on the own ship and carry out exercising drill to achieve the purpose of preventing pirate attacks. In case of distress, seamen can use the anti-piracy devices to deal with the pirates, and delay the time for aid. Through investigation, the anti-piracy devices on the ship includes Special infrared cameras, Titanium ray, grid system, powerful water cannon, repeating crossbows, the rockets parachute flame, high pressure water, body Armour and helmets, gasoline, electric billy, handcuffs, divulgeSteel goad, acoustic explosive, the remote controller sound waves, anti-piracy net, safety cabin, and so on.

\subsection{The coping strategy of crew}

To facing the pirates, the crew must set up confidence and combat them based on the self protection principles firstly. Second, the crew must report to the police in time and delay the time to aid.

\subsection{Strengthening the prevention and precaution}

In recent years, many cases of success from pirate attacks indicates, keeping on the alert and making effective precaution are the important guarantee of success from pirate attacks. Therefore, ship's piracy work shall be based on the "preventing". The key is that the pirate is discovered as soon as earlier, the ship sends the alarm and takes proper measures to prevent pirates get on the ship.

\subsection{Holding the position of the living quarters to build the best defense}

If the pirates had boarded already, the last measure to prevent is holding the position of living quarters of ship. Because the living quarters are higher than the deck area and are easier to defense, the pirates are difficult to enter the living quarters when the iron door is locked.

\subsection{The captain command effective and the crew share bitter hatred against the pirates}

In the crisis of pirate attacks, the captain must be calm, have a clear mind, agile thought, decisive action, appropriate command, taking a lead to combat the pirates.

\section{Conclusions}

The writer thinks that global societies cannot lower our guard and works should focus on the underlying reasons of piracy to achieve our goal of ocean beyond piracy. All respondents emphasized that piracy can only be eliminated permanently by addressing its root causes through development projects - an economic solution to an economic problem. 


\section{References}

[1] Guo Z.Y, Discussion on marine anti-piracy measures [J]. China navigation,2009(4):110-114.

[2] Guo R.Y, Research on marine anti-piracy comprehensive mechanism[J]. Journal of Qingdao ocean shipping mariners college,2011(2);25-28.

[3] Guo Z.Y, Discussion on marine anti-piracy and anti-hijacking measures[J]. China navigation,2011(3):105-110.

[4] The China Ministry of Transport, Ship’s anti-piracy practical manual[S]. Beijing: Science Press, China.2008.

[5] Zhang J. J, Research on the international cooperation of combating Somali pirates[J]. Modern Law Science,2009(4):138-144.

[6] Qi D. Z, Discussion on marine anti-piracy multi-measures [J]. The 14th annual meeting of China association for science and technology,2012.

[7] Shi C.L, Su P, Discussion on the anti-piracy quality cultivation of china seaman[J]. Transportation Enterprise Management,2011(2):66-68.

[8] Zhang J.D, Thoughts on pirate problem and measures[J]. International Studies,2009(2):55-57.

[9] Lu F.H, International law analysis on Somalia pirates[J]. Journal of Graduate School of Chinese Academy of social sciences,2009(3):95-98.

[10] WWW.afp.com/ ,September 15, 2015: “Somali Perspectives on Piracy and Illegal Fishing”.

[11] WWW.oceanbeyondpiracy.org(2015): “The State of Maritime Piracy 2015”.

[12] WWW.IMO.org.cn/

[13] WWW.safety4sea.com/ 